\title{
25. The Return of the Chief: East Sepik Provincial
}

\author{
R.J. May
}

In 2007 the East Sepik Provincial seat was held by the prime minister, Sir Michael Somare. In fact, Sir Michael had held the seat since 1968, for 19 of those 40 years as prime minister. In 2007 most observers expected Somare to be reelected, but within the province there appeared to be some groundswell of antiSomare sentiment, fuelled by a belief that although East Sepik had provided the country's prime minister, and a good share of its cabinet ministers, for much of the post-independence period, the province had fallen behind other parts of the country in terms of economic and social development. Somare's home base in the Murik Lakes of the lower Sepik was said to be divided over its support for the National Alliance. In 2002, Somare had been opposed by 17 candidates, including a young businessman from the populous Wosera area, Allan Bird, who had promoted the introduction of vanilla as a cash crop during the boom in vanilla prices. At one stage of the count in 2002 Bird was actually ahead in the polling, having outvoted Somare in the populous Ambunti-Dreikikir, Maprik, Wosera-Gaui, and Yangoru-Saussia open electorate areas. Somare was re-elected in 2002, but his share of the first-past-the-post vote dropped from 61 percent in 1997 to 23 percent in 2002. Bird did not stand in 2007, but 10 other candidates stood, and with the introduction of limited preferential voting (LPV) there was some speculation that preferential voting might bring a change. It was not to be.

\section{The electorate}

East Sepik Provincial is one of the country's largest electorates. At over 44,000 square kilometres, East Sepik is, by area, the second biggest province in Papua New Guinea. The electorate's boundaries extend along the north coast from just below the mouth of the Sepik River to a point about 70 kilometres west of the provincial capital, Wewak, including the islands of Mushu, Kairiru, Walis, Tarawai and the Schouten group and reach back south to the foothills of the central Highlands and west along the Sepik River to within about 35 kilometres of the border with Indonesia. Geographically, the electorate is dominated by the Sepik River and its major southern tributaries, the Keram, Yuat and Karawari. Between the river and the coastline lie the Prince Alexander and the Torricelli ranges, which to the north are thickly covered in rainforest but whose southern 
foothills give way to secondary forest and grasslands that merge with the Sepik floodplain to the southeast (May 1997:230). The size and geography of the electorate pose problems for electoral administration and campaigning.

Most of the province's population - an estimated 341,583 at the 2000 census - is concentrated in the southern foothills of the Prince Alexander Range and along the north coast, although there is a sizeable population in the grasslands south of Angoram and along the Keram and Yuat rivers and in a few big Sepik River villages. The Maprik District accounts for over 40 percent of the province's population, with population densities of more than 50 persons per square kilometre in the Wosera area. In contrast, much of the Ambunti district and parts of the Angoram district are sparsely populated.

Within East Sepik there are six Open electorates: Ambunti-Dreikikir, Angoram, Maprik, Wewak, Wosera-Gaui and Yangoru-Saussia (Figure 25.1). Prior to the election in 2007, two of these seats were held by National Alliance members (Angoram by Sir Michael Somare's son, Arthur), two by the Peoples Action Party, one by the Pan Melanesian Congress, and one by the National Transformation Party.

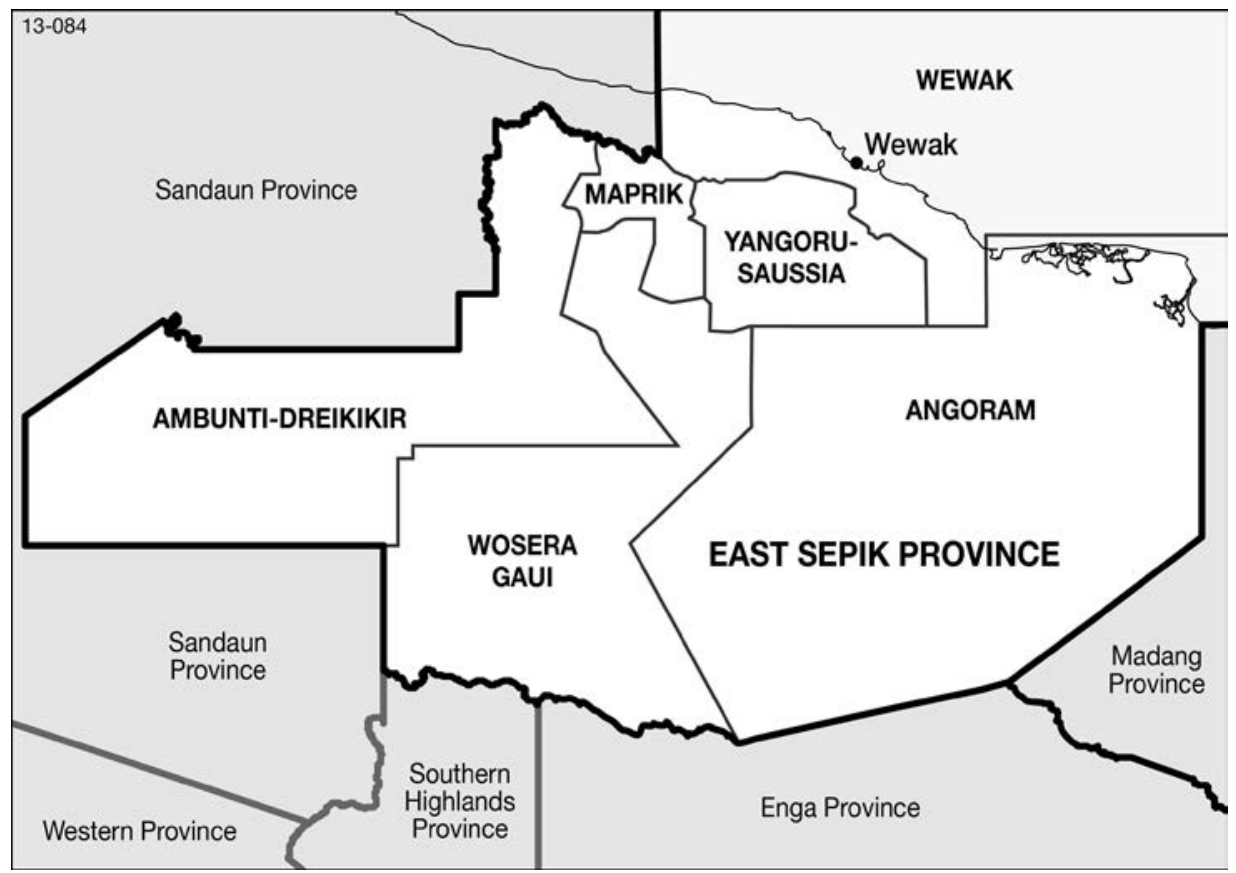

Figure 25.1: East Sepik open electorates 


\section{The candidates}

Eleven candidates contested the East Sepik Provincial seat. Apart from Somare, four (Maisen, Murray, Kemaken and Samban) had stood in 2002.

Greg Maisen, aged about 47, with a Bachelor of Arts degree from the University of Papua New Guinea, was formerly deputy provincial premier under Bruce Samban. From Miamboru village in West Yangoru, Maprik District, Maisen expected to receive strong support in the populous areas of Maprik, Wosera, Dreikikir and Yangoru-Saussia as well as through his membership of the New Apostolic Church. Maisen had stood for the Provincial seat in 1997 and 2002 and in the Yangoru-Saussia by-election of 2004, as endorsed People's Progress Party candidate. In 2007 he was approached by People's Progress Party (and also, he said, by the PNG Party), but decided instead to stand as a New Generation Party candidate.

Elizabeth Simogun Bade, aged 59, was the sole woman candidate in East Sepik Provincial. ${ }^{1}$ The daughter of a famous Sepik leader from the Boiken-Dagua (west coast) area, Elizabeth Simogun Bade was herself a distinguished public servant before resigning to contest the 2002 national election in Central Province. She returned to Wewak in 2003. Like the majority of East Sepik candidates, Simogun Bade was a member of the Roman Catholic Church, and was also associated with the National and East Sepik Councils of Women (currently as executive officer of the latter) and with Help Resources (a local non-government organization). She had stood unsuccessfully for the East Sepik provincial electorate in 1987 and in the Kairuku-Hiri (Central Province) electorate in the national elections of 2002; in 2007 she stood as an independent, hoping to poll well along the west coast and to attract the women's vote - fully aware, however, that women do not always support a female candidate. Simogun Bade was assisted as campaign manager by her half-sister, a former policewoman, and did some joint campaigning with Greg Maisen and Alfred Jambran.

Peter Bimare, aged 46, is a former journalist with the Wewak-based Wantok newspaper, and had founded a local paper, Toktok. He is from Magopim village on the west coast near Dagua.

Samuel Lamin, aged 42, followed a grade 10 education with a diploma in religious studies, and trained for a while with the Capuchin fathers. $\mathrm{He}$ described himself in 2007 as a storekeeper and street vendor and was also a village court magistrate. He had contested council elections in Wewak Town in 1997, unsuccessfully. Lamin was born at Yangimangua in Wosera-Gaui electorate

1 Five other women contested in East Sepik: three in Wewak Open and one each in Wosera-Gaui and Yangoru-Saussia. 
but lives in the Wewak village of Nuigo. His wife is from Maprik. He sought, but was declined, endorsement from People's Democratic Movement and stood as an independent, expecting to get support from Nuigo and, through his wife's connections, Maprik and Wosera. His campaign, such as it was, was linked to those of Francis Kemaken and Alfred Jambran.

Alfred Jambram, aged 38 and described as self-employed, was the sole candidate from the populous Dreikikir area to the west of Maprik where he was involved in vanilla growing and buying. He had stood unsuccessfully in the AmbuntiDreikikir electorate in 2002.

Gabriel Laku, from the large Sepik River village of Timbunke, heads the local branch of Redress Association International (which pursues compensation for victims of Japanese occupation during the Second World War) and used this network to mobilize votes. He was endorsed by the People's Resources Awareness Party.

Moses Murray, 53, is a Port Moresby-based private lawyer with a degree from the University of Papua New Guinea. He comes from Kairiru Island, off the coast from Wewak, but spent part of his early life in Maprik, and is married to a woman from Passam village, outside Wewak. Murray had contested the East Sepik provincial electorate, as an independent, in 2002, coming third behind Somare and Bird. In 2007 he stood as leader of the People's Freedom Party, and claimed to be in alliance with Greg Maisen, Elizabeth Simogun Bade and Alfred Jambran. His campaign was linked with that of Patrick Harriknen, another lawyer and People's Freedom Party-endorsed candidate contesting YangoruSaussia. A number of voters, however, regarded Murray as a 'Moresby man'.

Silas Suagu, 54, is from Kinaguie village in East Yangoru. He was endorsed by the Stars Alliance Party, but I did not catch up with him during the campaign and no other information was available.

Sir Michael Somare, aged 71 in 2007, had been the member for East Sepik Regional/Provincial since 1968. He had become chief minister in 1972 and led the country to independence in 1975 as prime minister. Somare's home village is Karau, at the mouth of the Sepik River in the Angoram electorate, of which his son, Arthur, is the sitting member. Somare was a foundation member of Pangu Pati but following a dispute within the party formed the National Alliance in 1997 and has been its parliamentary leader since its foundation. With the introduction of a local honours system in 2005, Somare became Grand Chief.

Francis Kemaken, aged 45, with secondary education and diplomas in religious studies and mission foundation from the Philippines, is a social worker with the Roman Catholic Church in Wewak, and a member of Caritas PNG, Help Resources, the East Sepik Council of Women, and the East Sepik Land and 
Environment Foundation. He stood unsuccessfully for East Sepik Provincial in 2002. Kemaken is from Chambri on the Sepik River but lives in Wewak and expected most of his support to come from Wewak town, where there is a large Chambri community. He was campaigning (on a modest scale), as an independent, with two other candidates, Samuel Lamin and Alfred Jambran, who had agreed to direct preferences to one another.

Bruce Samban was a last-minute nomination (having initially thought about standing in Wewak Open). Samban, aged 52 and with a grade 10 education, was a National Broadcasting Corporation announcer before becoming provincial premier in 1987. In 1991 his government was suspended; subsequently the provincial headquarters building was burned down, and Samban spent three years in the Boram Corrective Institution. Born in Kaminabit on the Sepik River, Samban lives in Wewak but has strong links, through a second wife, to the west coast (where he is related, by marriage, to another Provincial candidate, Elizabeth Simogun Bade). Samban stood unsuccessfully for the Provincial seat in 2002, with endorsement (but no financial assistance) from the People's Labour Party. He is a member of the Roman Catholic Church and a founder of the locally based Sepik Solidarity, a group which describes itself as being committed to exposing corruption in the province. Samban stood as an independent.

\section{The parties}

In the lead-up to the election, the coalition parties resolved that they would not endorse candidates against Somare in East Sepik, and there was no apparent evidence that any of them supported 'undercover candidates' in the provincial electorate. Of the 11 candidates who stood, five (Somare, National Alliance; Maisen, New Generation Party; Laku, People's Resource Awareness Party; Murray, People's Freedom Party, and Suagu, Stars Alliance Party) had party endorsement; two (Somare and Murray) were party leaders.

The National Alliance had its headquarters in a modest building near the airport, which served as a meeting place for candidates and scrutineers as the election got under way, though Somare conducted his campaign from his home in Wewak.

Bart Philemon visited Wewak early in the campaign to support Maisen and the six New Generation Party candidates standing in Open electorates in East Sepik. He also visited Somare's home base of Karau, in the lower Sepik, and planned to hold a rally on the Prince Charles Oval in Wewak to launch the East Sepik branch of the New Generation Party, but was told by police that he had no authorization to do so and would be arrested if he proceeded; the rally was cancelled. Many people, even National Alliance supporters, felt that the police 
reaction was inappropriate - an editorial in the Post-Courier described it as 'shameful' - and that it was evidence of the National Alliance's undue influence over public officials in the province. The prime minister and the National Alliance, however, denied any involvement and condemned 'a few unruly people' who had disrupted the New Generation Party's activities in Wewak. (See Post-Courier and The National 9, 10 January 2007.)

Otherwise, apart from a few posters there was little evidence of party activity. Maisen said he had received K30,000 and some posters from the New Generation Party, and that the New Generation Party and People's Freedom Party were waging an 'aggressive' campaign against Somare, but it appeared to be low key. Murray, like the independents, was self-funded.

\section{The campaign}

The campaign in East Sepik in 2007 was fairly subdued. Posters were on display on buildings around Wewak and in the various district headquarters, and in some villages, and candidates were moving around the province, mostly addressing small rallies or village meetings arranged by their supporters. Elizabeth Bade probably travelled most widely, assisted by her son, a helicopter pilot. As the only woman candidate, and with associations with both the National and the East Sepik Councils of Women, Simogun Bade hoped to be able to mobilize a 'women's vote', and several observers suggested that some mobilization did take place, especially in the Wewak islands, but Simogun Bade herself had modest expectations. According to some observers, however, she alienated voters by her aggressive criticism of Sir Michael Somare. Maisen, and to a lesser extent, Murray, Samban, and Suagu covered a good part of the province, mostly by vehicle, and had networks of supporters, including Open candidates and in Samban's case former Provincial members, campaigning on their behalf. Somare travelled within the province by vehicle and helicopter, sometimes in the company of his son, the member for Angoram, but seemed to be running a somewhat low-key campaign. A planned National Alliance rally in Wewak a week or so before polling commenced did not eventuate. There were allegations that the National Alliance was handing out funds, and specific reference to the release of $\mathrm{K} 600$ million for special infrastructure projects in the province (see Sydney Morning Herald 19 March 2007; Post-Courier 4 May 2007), but I saw no evidence of handouts - indeed at one point National Alliance supporters staged a brief demonstration outside campaign headquarters protesting that they had not received food. There seemed to be none of the candidates' vehicles covered in posters and equipped with loudspeakers that characterized earlier elections. Five candidates (Bimare, Lamin, Laku, Kemakin and Jambran) seem to have made little attempt to campaign at all outside their immediate support base. 
At the few rallies I attended there was the usual talk about why East Sepik Province had fallen behind in development (in 2002 the same complaints were made, though the province was at the time enjoying a vanilla boom), and complaints about declining service delivery and corruption. Most candidates promised local development. Somare spoke about prospective development projects in the province, including large-scale sago processing, and extensions to the Wewak wharf and airstrip. Samban, campaigning along the west coast, pointed to local roads that had been constructed during his term as premier but had been allowed to deteriorate by subsequent administrations and promised to address the question of local service provision. The one mention I heard of HIV/ AIDS was from a candidate who dismissed HIV/AIDS as a 'lifestyle issue' which was not relevant to village people in the Sepik, who would rather see money spent on 'development'; he was warmly supported in this view.

A topic of common concern was the growing Asian influence in the province (and nationally). A number of voters suggested that the Somare government (and indeed the Somare family) was too closely associated with Asian interests. One candidate in the Wewak Open electorate, a local businessman of Malaysian Chinese origin (married to a niece of Somare), was said to be an 'undercover candidate' for the National Alliance; when votes were counted and preferences distributed, he was placed third in a field of 43 candidates. Another alleged National Alliance 'undercover candidate', who subsequently won the Wewak seat and promptly joined the National Alliance, was rumoured to be receiving financial support from a local 'Chinese' business - which some voters described as 'namba 2 benk bilong dispela gavman'. The sitting members for Maprik (a minister in the outgoing coalition government) and Ambunti-Dreikikir were also said to be receiving support from a local Asian enterprise. ${ }^{2}$ The resentment towards Asians was directed less towards those with a long history in the province, however, than towards recent arrivals from mainland China who generally displayed little sensitivity to local culture or society.

Although the election was generally quiet, a supporter of the sitting member for Wewak Open was killed by supporters of a rival candidate when he attempted to campaign in their village outside Wewak, and there were at least two separate incidents in the Maprik electorate, in which a young man allegedly disrupting voting was shot in the leg by police and a police vehicle was damaged when villages accused its driver of acting on behalf of the sitting (coalition) member. Paol and Gesch (chapter 24) also describe some relatively minor confrontations between candidates and their supporters in Yangoru-Saussia.

Several of the Provincial candidates campaigned in association with sympathetic Open candidates as they moved around the province, and there was some talk about exchange of preferences between Provincial candidates (Bade-Maisen;

2 Both businesses were actually owned by ethnic Chinese families from Indonesia. 
Jambran-Bade; Maisen-Bade-Bimare; ${ }^{3}$ Murray-Bade-Jambran; ${ }^{4}$ KemakenLamin-Jambran, and perhaps others), but there does not seem to have been much discussion of preferences during campaigning - even though six of the candidates (Bimare, Lamin, Jambram, Suagu, Kemaken and Samban) shared membership of Sepik Solidarity, an anti-corruption (and in effect anti-National Alliance) alliance. Most candidates asked for first preferences, or second preferences if they were in villages where there was known to be a favoured local candidate. When pressed on the question of preference strategies, most candidates or campaign managers admitted that their general advice to voters was to 'vote 1 ' for them and to give the second and third preferences to minor (or rabis) candidates. But while candidates adjusted their advice on preferences according to their audience, candidates' posters mostly showed the candidate's number and/or name against the ' 1 ' but left the spaces beside ' 2 ' and ' 3 ' blank, a practice which some observers feared might cause confusion and lead to a high informal vote.

\section{Electoral administration}

\section{Awareness}

Prior to the election, an awareness campaign was conducted in the province, primarily by electoral officials. Civil society organizations played a minor role. A limited survey, conducted as part of the Domestic Monitoring exercise, suggested that most people in Wewak had had some exposure to the awareness campaign, which focused on the technical aspects of LPV, and felt fairly confident in their understanding of the new system and their ability to cast a valid vote, but that the campaign had not reached the more remote parts of the province. In the Yangoru-Saussia electorate voters had already experienced LPV, through a by-election in 2004 , and seemed to be generally more confident. During the election campaign, most candidates tried to explain the LPV system to prospective voters, perhaps to make sure that potential support was not wasted in informal votes. Although the awareness campaign appears to have had limited impact, informal voting was fairly low (overall 2.3 percent).

\section{Training of electoral officials}

According to the provincial electoral manager, training of electoral officials had been conducted satisfactorily, though the release of funds from the Papua New Guinea Electoral Commission headquarters was somewhat tardy. The polling

3 Maisen said he was happy to swap preferences with anyone except Somare, Suagu and Murray. 
officials, who comprised about 50 percent women in Wewak and a smaller number in rural polling stations, certainly conducted a thoroughly professional operation, not without some problems as it became apparent that a number of voters' names were not on the roll (see below). There was a little apprehension on the eve of counting, and the training consultant was brought up to Wewak to give a refresher briefing to officials on the eve of counting. The counting I witnessed (of Wewak Open and East Sepik Provincial ballot papers in Wewak) was well set up, transparent and orderly; officials again showed a good deal of professionalism and patience as losing candidates tried to disrupt the counting (see below).

\section{Logistics}

Preparations for the election seem to have been generally good, though some of the polling materials arrived only a day or two before polling was due to start. East Sepik Provincial is a large electorate with a number of remote polling places, and transport can be difficult, especially when the Sepik River is low, as it was in June-July 2007. Consequently, helicopters were used and some polling officials had to walk in to polling places. On the eve of polling, the helicopter company sub-contracted by the principal company contracted by the Papua New Guinea Electoral Commission informed a meeting of the provincial coordinating committee that aviation fuel, provided by the contractor, had only just been loaded onto a ship for transportation from Lae and would not be available to start operations on time. Fortunately, the subcontractor, previously unaware of this arrangement, had already deposited fuel at strategic points, but was reluctant to begin operations without a guarantee of payment for the fuel it provided. This potential crisis was resolved in time for polling officials and materials to be lifted out to their destinations with only a minor delay, but there were conspiracy theories that since Sir Julius Chan was a director of the principal contractor, the fuel issue was an attempt to disrupt the election in the prime minister's province. A fuel shortage in Wewak also threatened to affect road transport, though any impact seems to have been minimal. Otherwise, things seemed to go fairly smoothly, except that the day polling commenced the electoral manager, whose home village was on Kairiru, disappeared to Kairiru and did not return until counting was nearly completed (he later claimed he had been 'threatened'). In his absence, the provincial returning officer had to take effective charge of the election and resolve disputes that arose.

As usual in Papua New Guinea elections, after polling, some electoral officials claimed they had not received their full allowances, but in at least one instance this appeared to rest on a misunderstanding. ${ }^{5}$

5 In Wewak polling took place on one day (with a carryover to a second day at one or two polling stations); officials were paid for four days, but claimed they were entitled to allowances for 14 days, and staged a protest outside the provincial electoral office. 


\section{The roll, and polling}

As in other provinces, new rolls had been drawn up prior to the election and sent out for verification. In East Sepik the number of names on the roll was reduced significantly, from 286,716 in 2002 to 237,070 in 2007. In the limited survey conducted as part of the Domestic Monitoring exercise, most respondents said they had registered to vote and had verified their names on the preliminary roll sent around before polling (though there was anecdotal evidence that in some villages people refused to register). When it came to voting, however, a number of people who claimed to have enrolled (around 10 percent of voters at polling places surveyed in Wewak but up to 20 percent in some rural polling places) were unable to find their names on the ward rolls. In some cases it was discovered that individual names had been put in the wrong village, or villages in the wrong ward, and with some effort people were able to vote. In one district, the returning officer reverted to the preliminary roll, which was more accurate.

Despite this, voting in the province was generally peaceful and orderly, and what grievances arose were handled mostly without rancour, though disgruntled would-be voters in Wewak at one stage during the counting threatened to burn down the Wewak council chambers which was serving as the local media centre.

In Wewak, people queued up to vote throughout the day, and at a few locations polling was extended till around $6 \mathrm{pm}$ or resumed the next day, to ensure that voters were not denied their vote. In many rural villages voting was conducted by having the presiding officer call out the names from the roll, and also any nominated 'assist' and 'witness' (who in many cases were young women) for voters requiring an assisted vote. Voters then came forward, had their fingers checked to make sure they had not voted already, and were given ballot papers. This made the whole process quite transparent and any attempt at cheating would have been fairly obvious. Nevertheless there were some reports of underage voting and multiple voting at different polling stations. The requirement of separate polling compartments for women and men was not observed in East Sepik, but no one seemed to object to this. In some communities people said they had discussed how they should vote and would vote as a bloc, but I saw no evidence of voters being pressured on how to vote (though some observers believed that 'witnesses' were often checking, on behalf of candidates, on how people voted).

\section{Security}

Security for the election was provided by the regular police force stationed in East Sepik and several hundred community police. Moem Barracks in Wewak is home to the Papua New Guinea Defence Force's 2nd Battalion RPIR, 
and the defence force was represented on the provincial election coordinating committee, but defence force personnel were not deployed during the election in East Sepik, except as security when counting took place for the Wewak and Yangoru-Saussia open electorates at Moem Barracks. Police accompanied polling teams (two police to an eight-person polling team) and there were generally several community police on hand at polling stations. Relations between police and polling officials, and with voters, seemed to be generally good, and I saw none of the heavy-handedness which reportedly marked the police presence at some Highlands polling stations.

The elections in East Sepik were expected to proceed peacefully in the province, but a few places were identified as potential trouble spots, including the area along the East Sepik-Enga border (where groups from Enga have regularly sought to cast votes in East Sepik), some villages along the Biwat River (a southern tributary of the Sepik), around Yangoru, and along the Dagua-west coast. In the event, there were no major problems.

\section{Counting}

As voting proceeded, there was an intensified debate about where to do the counting. Several venues discussed as counting places were later dropped due to non-availability or concerns by some candidates about security. Eventually it was decided to count the Wewak votes at Moem Barracks, where security was tight, and to count the Provincial ballots at the Divine Word University campus (formerly St Benedict's Teachers' College) at Kaindi, on the outskirts of Wewak.

Counting was scheduled to commence on Saturday but did not get under way until $7.45 \mathrm{pm}$ on the Monday. The counting room was well laid out, security was strict, the counting officials were competent and the whole process was transparent. Figures were carefully balanced and as each ballot box was counted the figures were displayed on a large blackboard, relayed to Port Moresby, and subsequently put on display outside the local media centre.

In a few cases figures did not balance and had to be recounted. Most of the Provincial ballot boxes contained a few ballots for the Open electorate; these were put aside and later exchanged with Provincial ballots that were found in the Open ballot boxes.

Soon after counting commenced, however, the scrutineers of some losing candidates began to raise what seemed to be rather minor objections, ${ }^{6}$ and walked out. The provincial returning officer felt obliged to halt counting. With

6 The principal objection was that the plastic seal on one of the ballot boxes was broken - as happened in a number of cases throughout the country; but there had been no objection raised when the box was brought 
the election manager unavailable, the provincial returning officer reluctant to act without backing from higher up, and a legal adviser to the Papua New Guinea Electoral Commission present but generally unhelpful, it eventually fell to the regional police commander from Lae (who was previously provincial commander in East Sepik and was well known and respected in the province) to order that counting recommence, which eventually it did, with some scrutineers not attending. As a result of these interruptions, counting officials sat around for long periods with nothing to do, and on a couple of occasions counting went on till $4 \mathrm{am}$. They were remarkably patient.

\section{The result}

As the first votes were counted, Somare's opponents' hopes of an upset began to fade. In the first 40 ballot boxes (all from the Wewak district) Somare was a clear winner in all but six (in which Bade, Murray, Samban and Maisen pulled in votes from their support bases), and had about 40 percent of the total vote.

When first preference votes had been counted, Somare led strongly, with 60,653 votes, almost twice the number received by his next nearest rival (Maisen on $31,460)$ and about 35 percent of the total allowable votes. However, it took a full elimination of candidates to decide the outcome (Table 25.1).

Table 25.1: Distribution of preferences, East Sepik provincial electorate

\begin{tabular}{llrrrrrrrr}
\hline Excl & Candidate & Maisen & Bade & Jambram & Murray & Somare & Other & $\begin{array}{r}\text { Ex'ed } \\
\text { ballots }\end{array}$ & Total \\
\hline 1 & Bimare & 34 & 92 & 33 & 32 & 48 & 74 & 3 & 316 \\
2 & Lamin & 107 & 111 & 260 & 112 & 103 & 231 & 2 & 926 \\
3 & Laku & 293 & 372 & 214 & 507 & 196 & 261 & 9 & 1,852 \\
4 & Suagu & 429 & 462 & 160 & 522 & 443 & 235 & 41 & 2,292 \\
5 & Samban & 492 & 594 & 225 & 720 & 515 & 303 & 125 & 2,974 \\
6 & Kemaken & 641 & 1,073 & 540 & 1,117 & 798 & - & 366 & 4,535 \\
7 & Bade & 3,896 & - & 2,238 & 5,937 & 3,826 & - & 1,643 & 17,540 \\
8 & Jambram & 7,035 & - & - & 10,927 & 3,123 & - & 6,482 & 27,567 \\
9 & Maisen & - & - & - & 19,817 & 5,602 & - & 18,982 & 44,401 \\
& Total & 12,927 & 2,704 & 3,670 & 39,691 & 14,654 & 1,104 & 27,653 & 102,403 \\
\hline
\end{tabular}

On the first elimination, Bade received the largest share (almost a third) of Bimare's meagre vote, and on the second, Jambram was by far the greatest beneficiary from Lamin's elimination, with the other four prominent candidates sharing in the remainder of his preferences. On every other preference distribution - as first

in and the broken seal explained. One scrutineer confided to me that the National Alliance had been altering the figures inside the ballot boxes; when I asked him how this could be done, he replied that (as I surely knew) it was done through blak paua (magic). 
Labu and then Suagu, Samban, Kemaken, Bade and Maisen were eliminatedMurray gained the largest share of the growing number of preferences. On each of the third to sixth eliminations Bade got the second largest share; unfortunately for Bade, however, despite her success in winning preferences her primary vote was well below that of four other candidates and after the sixth distribution she was eliminated. Almost 6000 of Bade's preferences went to Murray, with Maisen receiving about the same number as Somare (3896 to 3826). In the last two eliminations (Jambram and Maisen) Murray received 30,744 preferences to Somare's 8725, but Somare's share was sufficient to give him a narrow victory-relative to his early lead-by 75,293 to 67,437 . Of the 170,380 allowable ballots, a high 142,727 (84 percent) remained in the count up to the final elimination, a percentage which is generally regarded as indicative of a 'good' use of preferences by voters. Somare's winning vote represented 44 percent of the total allowable ballots cast.

Murray lodged an appeal, but it was dismissed because the petition had not been served within the time period required by court rules (John Nonggorr, personal communication 8 October 2009).

Subsequently, as the leader of the party with the largest number of seats Somare was invited to form a government, and when the national parliament sat in August Somare was re-elected as prime minister.

\section{Assessment of the electoral outcome}

Sir Michael Somare, the long-serving prime minister, the member for East Sepik since 1968 and the man who led his country to independence, is a popular figure in the province, though perhaps one whose popularity has been on the wane over the past few years, as many East Sepiks complain about lack of development in the province and suggest that the Somare family (Sir Michael and his son Arthur, the re-elected member for Angoram) wield too much power, provincially and nationally. Given that the contest in East Sepik Provincial was in effect a contest between Somare and 10 candidates who might be described as 'anti-Somare', it is perhaps not too surprising that preferences flowed fairly consistently away from Somare, though he eventually received enough to achieve re-election. LPV thus did not bring about a different result in the East Sepik provincial electorate from what, on the basis of first preferences, a firstpast-the-post vote might have delivered, but it did reveal a growing antipathy towards the sitting member which might not have otherwise been evident. 
The sole woman candidate, Elizabeth Simogun Bade, could take encouragement from her strong showing on preferences - which might have reflected a (qualified) women's vote - but it was again demonstrated that preferences are of little use if a candidate does not do well enough in the primary vote. ${ }^{7}$

Several candidates expressed the view that LPV had made for a 'more friendly' election, though, as noted, there was little evidence that the new system produced a tendency towards strategic alliances through preference swapping.

Elsewhere in the province, four six of the sitting Open members retained their seats. After the independent Jim Simutab (Wewak Open) had joined the National Alliance, the East Sepik's seven members of parliament comprised four National Alliance members and three People's Action Party.

\section{References}

May, R. J., 1997. 'East Sepik Province 1976-1992', in R. J. May and A. J. Regan with A. Ley (eds), Political Decentralisation in a New State: The Experience of Provincial Government in Papua New Guinea. Bathurst: Crawford House Publishing, pp. 228-261.

\section{Appendix}

Table 25.2: Voting statistics for East Sepik Provincial electorate, 2007 election

\begin{tabular}{lrl}
\hline Number of registered voters & 240,551 \\
Total votes cast & 174,215 \\
Informal votes & $3,835 \quad$ (2.2\% of ballots cast) \\
Total allowable ballot papers & 170,380 \\
Total ballot papers remaining in count & 142,730 \\
Total votes distributed & 81,984 \\
Exhausted ballot papers & $27,650 \quad$ (16.2\% of allowable ballots) \\
Absolute majority $(50 \%+1)$ & 71,366 \\
\hline
\end{tabular}

7 A similar result had been seen in the Yangoru-Saussia by-election in 2004, in which the sole woman candidate was unable to take advantage of a strong preference vote because her primary vote was relatively low. 
25. The Return of the Chief: East Sepik Provincial

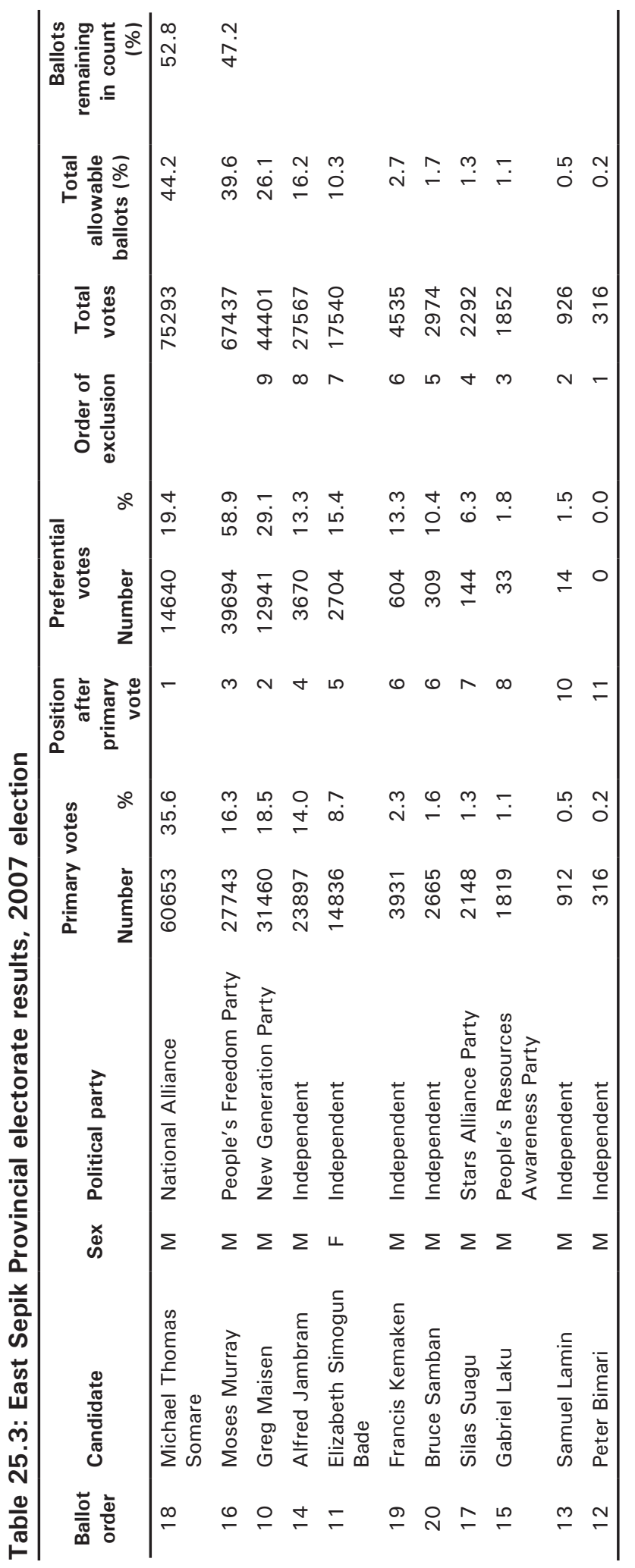

